\title{
TERAPI BERMAIN ULAR TANGGA UNTUK MENINGKATKAN PERKEMBANGAN BAHASA ANAK USIA 5-6 TAHUN
}

\section{Atik Pramesti W, Leny andiyanti, Achmad Effendi ${ }^{1}$ Stikes Banyuwangi Jl. Letkol Istiqlah No. 109 Banyuwangi ${ }^{1}$}

Kutipan: Atik Pramesti W, Leny andiyanti, Achmad Effendi. (2017). Terapi Bermain Ular Tangga Untuk Meningkatkan Perkembangan Bahasa Anak Usia 5-6 Tahun. Jurnal Keperawatan Muhammadiyah, 2 (2)

Korespondensi
Atikpramesti
@stikesbanyuwangi.ac.id
ABSTRACT

Developmental disorders that are often encountered in preschool children is a disorder of language development. Speech delays will be at risk until young adulthood because it will have learning difficulties that lead to less academic achievement. In an effort to optimize child development, a child-centered method of playing snake ladder is used, allowing children to actively interact and explore their environment. This study aims to determine the effectiveness of therapeutic snake play on the development of preschool language children aged 5-6 years. This study used pre experimental one group pre-post test design. The sample of this study were children aged 5-6 years who experienced a delay in language development amounted to 27 respondents taken with total sampling technique. The independent variable

Keywords: Keyword: children aged 5-6 years, language development, playing ladder snakes in this research is the ladder snake play therapy. Dependent variable is language greeting in 5-6 years old children measured using DDST. The Wilcoxon Signed Ranks Test test shows that there is a difference between before and after intervention on the development of a child language with $p=$ 0,000. Playing a ladder snake has benefits for the left and right brain of the child that the child will learn to know numbers, count steps, get to know the picture, and memorize the picture. This play method can be developed by health workers in the health center in providing therapy to children who experience speech delay. 


\begin{abstract}
ABSTRAK
Gangguan perkembangan yang sering ditemui pada anak prasekolah adalah gangguan perkembangan bahasa. Keterlambatan bahasa akan beresiko sampai usia dewasa muda karena akan mengalami kesulitan belajar yang menyebabkan pencapaian akademik kurang. Sebagai upaya untuk mengoptimalkan perkembangan anak, maka dilakukan metode yang terpusat pada anak yaitu terapi bermain ular tangga, yang memungkinkan anak secara aktif berinteraksi dan mengeksplorasi lingkungannya. Penelitian ini bertujuan untuk mengetahui efektivitas terapi bermain ular tangga terhadap perkembangan bahasa anak prasekolah usia 5-6 tahun. Penelitian ini menggunakan pre experimental one group pra-post test design. Sampel penelitian ini adalah anak usia 5-6 tahun yang mengalami kelambatan perkembangan bahasa berjumlah 27 responden yang diambil dengan teknik total sampling. Variabel bebas dalam penelitian ini adalah terapi bermain ular tangga. Variabel terikatnya adalah perkembahan bahasa pada anak usi 5-6 tahun yang diukur menggunakan DDST. Uji Wilcoxon Signed Ranks Test menunjukkan ada perbedaan antara sebelum dan sesudah intervensi pada perkembangan bahasa anak dengan nilai $p=0,000$. Bermain ular tangga memiliki manfaat bagi otak kiri dan kanan anak yaitu anak akan belajar mengenal angka, menghitung langkah, mengenal gambar, dan menghafal gambar. Metode bermain ini dapat dikembangkan oleh tenaga kesehatan yang ada di puskesmas dalam memberikan terapi kepada anak yang mengalami keterlambatan bicara/bahasa.
\end{abstract}

Kata Kunci: Anak usia 5-6 tahun, bermain ular tangga, perkembangan bahasa

\section{PENDAHULUAN}

Perkembangan anak pada masa pra sekolah merupakan tahap dasar yang sangat berpengaruh dan menjadi landasan untuk perkembangan selanjutnya (Adriana, 2013). Gangguan perkembangan sekecil apapun yang terjadi pada anak di usia prasekolah ini, apabila tidak terdeteksi dan diintervensi sedini mungkin akan mengurangi kualitas sumber daya manusia di masa akan datang (Febrikaharisma, 2009). Keterlambatan bicara/bahasa akan beresiko sampai usia dewasa muda karena akan mengalami kesulitan belajar yang akan menyebabkan pencapaian akademik yang kurang (Susanti \& Neneng, 2015). Kemampuan bicara atau bahasa anak pra sekolah akan berkembang sejalan dengan rasa ingin tahu anak serta sikap antusias yang tinggi, sehingga timbul pertanyaan-pertanyaan dari anak dengan kemampuan bahasanya, kalimat anak sudah terdiri dari empat sampai lima kata dan mereka lebih banyak menggunakan kata kerja 
daripada kata benda (Wahyuning \& Agustin, 2011). Sementara itu berdasarkan data Badan Statistik Pusat Nasional tahun 2015 saat ini diperkirakan ada 351.000 anak yang mengalami

keterlambatan bicara/bahasa berada di bawah umur 6 tahun (Susanti \& Neneng, 2015). Gangguan perkembangan yang sering ditemui pada anak prasekolah adalah gangguan perkembangan bicara dan bahasa, diperkirakan angka kejadiannya berkisar antara $1 \%$ sampai $32 \%$ pada populasi normal (Soetjiningsih \& Ranuh (2014). Prevalensi keterlambatan bicara pada anak usia prasekolah bervariasi. Prevalensi keterlambatan bicara dan bahasa pada anak usia 5-6 tahun adalah 5-8\% (Rahayu, 2013). Sedangkan di Indonesia mendeteksi adanya gangguan bicara dan bahasa pada anak usia prasekolah mencapai $12 \%$ - 28\% dari 33.265 .379 anak pada usia prasekolah (Sri Rahayu, 2013). Dari data yang di dapat dari catatan Dinkes Provinsi Jawa Timur, terdapat $2 \%$ dari 4.208 .173 anak usia prasekolah yang mengalami gangguan dalam bicara atau bahasa (Dinas Kesehatan provinsi Jawa Timur, 2011). Berdasarkan Profil
Kesehatan Kabupaten Banyuwangi menunjukkan bahwa dari 15.762 anak usia prasekolah sebanyak 457 $(2,9 \%)$ anak mengalami gangguan dalam bicara dan bahasa (Dinas Kesehatan Kabupaten Banyuwangi, 2015).

Ciri-ciri anak yang mengalami keterlambatan bicara/bahasa meliputi masalah artikulasi, suara tidak jelas, kelancaran bicara, kesulitan dalam menggunakan kata-kata serta keterlambatan dalam berbicara, hal ini dapat berlanjut sampai usia dewasa muda, selanjutnya orang dewasa dengan pencapaian akademik yang rendah akan mengalami masalah perilaku dan penyesuaian psikososial (Hurlock, 2014). Pendidikan pada masa usia dini merupakan wahana pendidikan yang sangat fundamental dalam memberikan kerangka dasar terbentuk dan berkembangnya dasardasar pengetahuan, sikap dan keterampilan pada anak. Bermain bagi anak berfungsi untuk mempermudah perkembangan kognisi anak. Kegiatan bermain sangat dinikmati anak dan mainan yang sangat disukai anak dapat digunakan untuk menarik perhatian 
serta mengembangkan kapasitas dan pengetahuan anak tersebut (Sugianto, 2010). Metode permainan ular tangga diberikan pada anak usia pra sekolah dengan harapan permainan dapat mengembangkan potensi yang ada pada diri anak. Permainan ini menimbulkan anak dapat memahami perintah, anak dapat menambah kosa angka baru, melatih anak belajar membaca angka, melatih anak memahami perintah serta melatih anak dalam berbicara terhadap teman sebaya (Raisatun, 2013). Proses perjalanan fisiologis dari terapi bermain ular tangga dapat mempengaruhi perkembangan bahasa anak. Pada anak usia 5-6 tahun perkembangan otaknya mengalami pembentukan hubunganhubungan atau koneksi dengan beberapa milyar sel saraf yang semua itu dipengaruhi dari faktor lingkungan, pola asuh orang tua dan faktor pembelajaran disekolah. Tujuan dari terapi bermain ular tangga adalah melanjutkan perkembangan yang normal,mengekspresikan keinginan, mengalihkan perasaan serta perkembangan kemampuan panca indera. Dalam bermain ular tangga sebagian anak mengunakan panca inderanya untuk melakukan kegiatan tersebut yang dapat melatih anak untuk dapat berkomunikasi dan berbahasa secara efektif (IDAI, 2011). Adapun tujuan penelitian ini adalah teridentifikasinya pengaruh terapi bermain ular tangga terhadap peningkatan perkembangan bahasa pada anak usia 0-5 tahun.

\section{METODE PENELITIAN}

Jenis penelitian adalah strategi untuk mencapai tujuan penelitian yang telah ditetapkan dan berperan sebagai pedoman atau penutupan peneliti pada seluruh proses penelitian (Nursalam, 2013). Jenis penelitian ini adalah pre experimental One Group pra-post test design yaitu kelompok subyek diobservasi sebelum dilakukan intervensi, kemudian diobservasi lagi setelah intervensi (Nursalam, 2013). Populasi dalam penelitian ini adalah semua anak yang berumur 5-6 tahun yang mengalami keterlambatan bicara/bahasa. Sampel diambil dengan teknik total sampling. Besar sampel dalam penelitian ini sebesar 27 responden. Variabel bebas merupakan variabel yang mempengaruhi atau yang menjadi 
sebab perubahannya atau timbulnya variabel dependen (Sugiyono, 2011). Variabel bebas dalam penelitian ini adalah terapi bermain ular tangga yang dilakukan 1 minggu 2 kali selama 4 minggu dengan durasi masing-masing pertemuan \pm 30 menit. Adapun jenis ular tangga yang digunakan pada penelitian ini adalah angka 1-20 dengan warna yang berbeda dan dengan gambar yang berbeda-beda. Alat ukur yang digunakan adalah satuan acara bermain. Variabel terikat merupakan variabel yang dipengaruhi atau yang menjadi akibat, karena adanya variable bebas (Sugiyono, 2011). Variabel terikat penelitian ini adalah perkembangan bahasa pada anak usia 5-6 tahun yang diukur menggunakan lembar DDST dan didapatkan $\geq 2$ caution atau $\geq 1$ keterlambatan, untestable : bila ada skor menolak pada $\geq 1$ uji coba terletak disebelah kiri garis umur atau menolak pada $\geq 1$ uji coba yang ditembus garis umur pada daerah 7590\%. Data kemudian diuji dengan Wilcoxon Signed Ranks Test dengan $\alpha \leq 0,05$.

\section{HASIL}

Penelitian ini dilakukan di TK Harapan Bangsa Banyuwangi bulan Agustus sampai September 2017. Hasil uji Wilcoxon Signed Ranks Test menunjukkan nilai $p=0,000$ artinya ada perbedaan kemampuan bahasa anak sebelum dan sesudah intervensi.

Tabel 1 Karakteristik responden berdasarkan jenis kelamin anak usia 5-6 tahun di di TK Harapan Bangsa Banyuwangi (Agustus-

\begin{tabular}{cccc}
\hline No & Jenis kelamin & n & \% \\
\hline 1 & Laki-laki & 15 & $56 \%$ \\
\hline 2 & Perempuan & 12 & $44 \%$ \\
\hline & Jumlah & 38 & $100 \%$ \\
\hline
\end{tabular}

September 2017)

DDST kit. Data yang didapat dari (Sumber: Leni, 2017)

skor selanjutnya diskoring sesuai dengan skala penilaian skor untuk perkembangan bicara/bahasa anak yang meliputi normal : bila tidak ada keterlambatan, suspect : bila 
Tabel 2 Karakteristik responden berdasarkan usia anak di TK Harapan Bangsa Banyuwangi (AgustusSeptember 2017)
Hasil uji menggunakan SPSS Wilcoxon Signed Ranks Test perkembangan bahasa anak menunjukkan nilai $p=0,000$.

\begin{tabular}{cccc}
\hline No & Usia & n & \% \\
\hline 1 & 5 tahun & 15 & $56 \%$ \\
\hline 2 & 6 tahun & 12 & $44 \%$ \\
\hline & Jumlah & 38 & $100 \%$ \\
\hline
\end{tabular}

(Sumber: Leni, 2017)

Tabel 3 Distribusi data perkembangan bahasa anak usia 5-6 tahun di TK Harapan Bangsa Banyuwangi (AgustusSeptember 2017)
Pada tabel 3 menunjukkan bahwa anak pra sekolah mengalami peningkatan perkembangan bahasa menjadi normal setelah diberikan

\begin{tabular}{cccccc}
\hline \multirow{2}{*}{ No. } & \multirow{2}{*}{ Perkembangan bahasa } & \multicolumn{2}{c}{ Sebelum } & \multicolumn{2}{c}{ Sesudah } \\
\cline { 2 - 6 } & $\mathbf{n}$ & $\mathbf{\%}$ & $\mathbf{n}$ & $\mathbf{\%}$ \\
\hline 1 & Normal & 0 & $\%$ & 14 & $52 \%$ \\
\hline 2 & Suspect & 10 & $37 \%$ & 12 & $44 \%$ \\
\hline 3 & Untestable & 17 & $63 \%$ & 1 & $4 \%$ \\
\hline & Total & 27 & $100 \%$ & 27 & $100 \%$ \\
\hline
\end{tabular}

(Sumber : Leni, 2017)

terapi bermain ular tangga berjumlah

Setelah dianalisis dengan uji Wilcoxon Signed Ranks Test menggunakan SPSS didapatkan hasil nilai sig (2-tailed) $0,000<0.05$. Maka Ho ditolak Ha diterima berarti ada pengaruh terapi bermain ular tangga terhadap perkembangan bahasa pada anak prasekolah usia 5-6 tahun Di TK Harapan Bangsa Banyuwangi Tahun 2017.

\section{PEMBAHASAN}

14 responden. Menurut Ernawulan (2008) perkembangan kemampuan berbicara anak usia 5-6 tahun adalah sudah dapat mengucapkan kata dengan jelas dan lancar, dapat menyusun kalimat yang terdiri dari enam sampai delapan kata, dapat menjelaskan arti kata-kata yang sederhana, dapat menggunakan kata hubung, kata depan dan kata sandang. Pada masa akhir usia taman kanak-kanak umumnya anak sudah mampu berkata-kata sederhana dan 
berbahasa sederhana, cara bicara mereka telah lancar, dapat dimengerti dan cukup mengikuti tata bahasa walaupun masih melakukan kesalahan berbahasa. Bermain merupakan suatu aktifitas yang memberikan stimulasi dalam kemampuan melakukan atau mempraktekan keterampilan, kognitif dan afektif, memberikan ekspresi terhadap pemikiran, menjadi kreatif, mempersiapkan diri untuk berperan dan berperilaku dewasa. Berbagai penelitian menyebutkan bahwa bermain mempunyai manfaat yang besar bagi perkembangan anak. Upaya untuk perkembangan bicara/bahasa itu sendiri adalah bermain ular tangga dimana pada permainan ular tangga memiliki manfaat bagi otak kiri dan kanan anak yaitu anak akan belajar mengenal angka, menghitung langkah sesuai dengan mata dadu, mengenal gambar, dan menghafal gambar (Hidayat, 2013). Menurut (Francisca, 2010) permainan ular tangga adalah permainan papan yang terbuat diatas media dua dimensi. Papan permainan dibagi dalam kotak-kotak kecil, sejumlah ular atau tangga digambar dibeberapa kotak yang menghubungkannya dengan kotak lain. Permainan ular tangga yang diterapkan dalam penelitian ini adalah permainan ular tangga berbentuk persegi panjang yang didesain oleh peneliti sendiri dimana permainan berisikan angka angka 120 dengan warna yang berbeda dan dengan gambar yang berbeda-beda yang digunakan untuk mengembangkan pola berfikir anak. Permainan ini dilakukan oleh peneliti 1 minggu 2 kali selama 4 minggu dengan durasi masing-masing pertemuan \pm 30 menit. Berdasarkan hasil penelitian yang dilakukan menunjukkan bahwa terdapat peningkatan perkembangan bahasa pada anak prasekolah usia 5-6 tahun setelah dilakukan terapi bermain ular tangga dari untestable ke normal dengan jumlah peningkatan 14 responden. Keberhasilan pelaksanaan terapi bermain ular tangga pada penelitian ini dikarenakan terapi bermain ular tangga merupakan kegiatan yang menyenangkan dan tidak membosankan dimana responden anak-anak diberikan kebebasan untuk bermain sepuasnya. Sebagian besar responden pada peneltian ini sudah mulai 
mengembangkan kemampuan berkomunikasinya dengan baik dan bersedia diajak bermain dengan menghitung angka dan menyebutkan gambar dan warna. Selama proses pelaksanaan terapi bermain ular tangga peneliti juga didampingi oleh guru kelas yang bertanggung jawab sebagai fasilitator dan membantu mengendalikan responden apabila ada anak yang kurang aktif maupun anak yang terlalu aktif.

Berdasarkan hasil penelitian didapatkan data bahwasannya anak dapat mematuhi peraturan permainan ular tangga, dapat menghitung dadu tanpa bantuan orang lain, dapat membaca angka, menyebutkan gambar dan warna, selain itu 14 responden mampu untuk

Permainan ular tangga dapat bersosialisasi dengan teman sekelasnya dan guru, sedangkan 12 menunjukkan bahwa anak pra sekolah responden memiliki perkembangan mengalami peningkatan perkembangan bahasa bahasa suspect dibuktikan dengan menjadi normal setelah diberikan terapi belum bisa mematuhi perinfah bermain ular tangga berjumlah 14 responden. permainan, bisa menghitung pada Keberhasilan pelaksanaan terapi bermain ular dadu tetapi masih melirik temannya, tangga pada penelitian ini dikarenakan terapi dapat menyebutkan angka masih dibantu oleh temannya tetapi dapat menyenangkan dan tidak membosankan menyebutkan warna dan gambar dimana responden anak-anak diberikan Permainan ular tangga ini dapat kebebasan untuk bermain sepuasnya. Sebagian dimainkan oleh orang tua bersama besar responden pada peneltian ini sudah mulai 
mengembangkan

kemampuan

berkomunikasinya dengan baik dan bersedia diajak bermain dengan menghitung angka dan menyebutkan gambar dan warna. Melalui metode permainan ular tangga ini diharapkan dapat menambah kosa kata baru anak melalui gambar dalam papan ular tangga tersebut.

\section{SARAN}

Hasil penelitian ini diharapkan dapat diaplikasikan oleh kader kesehatan berkolaborasi dengan guru dalam melakukan stimulasi dan optimalisasi perkembangan anak pra sekolah. Bermain ular tangga membentuk karakter anak secara tidak langsung. Sehingga perlu dikembangkan yaitu melalui pengarahan yang dilakukan kader kesehatan kepada orang tua dan guru.

\section{DAFTAR PUSTAKA}

Adriana. (2013). Education Games. Yogyakarta: Pilar Media.

Dinas Kesehatan Jawa Timur. (2011). Profil Kesehatan Provinsi Jawa Timur Tahun 2010. Surabaya: Dinas Kesehatan Provinsi Jawa Timur.

Dinas Kesehatan Kabupaten Banyuwangi. (2015). Profil Kesehatan Kabupaten Banyuwangi 2015. Banyuwangi. Dinas
Kesehatan

Kabupaten Banyuwangi

Ernawulan. (2008). Pengembangan Media Sederhana Ular Tangga Bertema Bagi Siswa Taman Kanak-kanak (Skripsi). UNY, Yogyakarta.

Febrikaharisma. (2009). Pendidikan Anak Usia Dini. Yogyakarta: Diva Press.

Hidayat. (2013). Pengantar Ilmu Keperawatan Anak 1. Jakarta: Salemba Medika.

Hurlock, Elisabeth. B. (2014). Perkembangan Anak, Edisi Keenam. Jakarta :Erlangga.

IDAI. (2011). Rekomendasi Ikatan Dokter Anak Indonesia Suplementasi Besi Untuk Anak. Jakarta: Badan Penerbit IDAI.

Nursalam. (2013). Konsep dan penerapan Metodologi Penelitian Ilmu Keperawatan Edisi 2 .Jakarta: Salemba Medika.

Rahayu. 2013. Efektivitas Penggunaan Media Permainan ular Tangga Dalam Mengembangkan Kemampuan mengenal Konsep Bilangan Anak Taman Kanak-Kanak. Bandung FIP: UPI

Raisatun. (2013). Seabrek Games Asyik- Edukatif untuk mengajar PAUD/TK. Jogjakarta: Diva Press.

Soetjiningsih, Gde Ranuh IGN. 2015. Tumbuh Kembang Anak. Jakarta: EGC Sugianto. (2010). 
Bermain, Mainan dan

Permainan. Jakarta: Dirjen

Pendidikan Tinggi

Sri Rahayu. (2013). Meningkatkan Kemampuan Anak Dalam Berhitung Melalui Permainan Ular Tangga. Diakses dari $\mathrm{http} / /$ respository.upi.edu/perp ustakaan.upi.edu/s_paud_070 1540_chapter1.pada tanggal 14 januari 2013.

Sugiyono. 2011. Statistika Untuk Penelitian. Bandung: Alfabeta

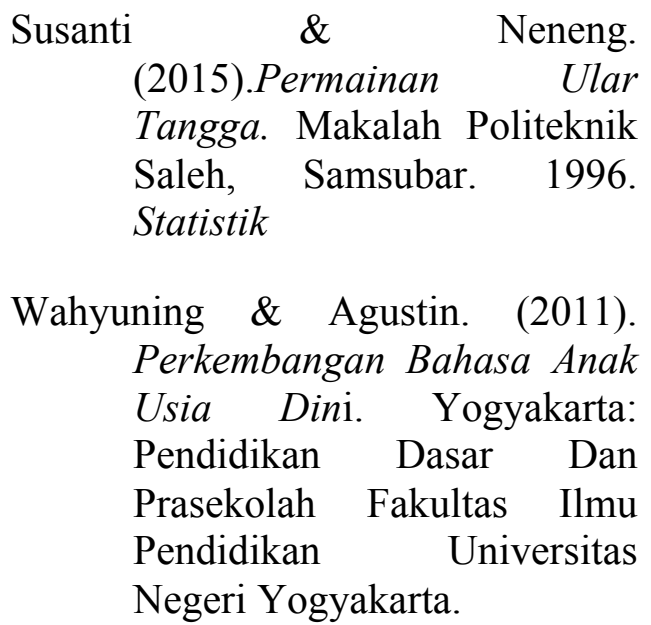

